\section{TIME FOR THE ECJ TO BECOME A SUPRANATIONAL COURT?}

During the last few years we have had much discussion on reforming the institutional framework of the European Union in order to enable it to cope effectively with a Community of 25 states. Most of the debate has centred on the legislative or decision-making bodies. The main unresolved issues are the membership size of the European Commission and the number of votes allocated to each Member State's representative in the EU Council.

As far as the Court of Justice of the European Communities ("ECJ") is concerned, the most significant reform took place in 1988 with the establishment of the Court of First Instance ("CFI"). This structural reform and more recent reforms have been undertaken mainly as a response to an increase in its workload. There is however no significant debate on the nature and size of the ECJ. This is a court which is primarily concerned with "constitutional" and interpretation issues that shape the Community's legal order as a separate and distinct legal order from national and international legal orders.

Although in Van Gend en Loos (1963) the ECJ held that the EC Treaty created "its own legal system" different from national and international law, ECJ judges continue to be appointed in a manner more common to appointments to international courts. The Community legal order, being separate from the international legal order, should have a supranationally appointed court. Is it not about time that consideration is given to the size of the ECJ (as opposed to the CFI, or any Panels that may be appointed under Article 225a EC Treaty) and the manner in which ECJ judges are appointed?

Article 221 EC Treaty states that "The Court of Justice shall consist of one judge per Member State" and Article 223 provides for the members of the Court to be appointed by "common accord of the governments of the Member States". In practice, each Member State appoints its own judge. The mechanism for choosing the national judge is not uniform and left entirely in the hands of each Member State. Although under Article 223 EC Treaty, the person chosen must "possess the qualifications required for appointment to the highest judicial offices in their respective countries or who are jurisconsults of recognised competence," they do not have to have any knowledge or expertise in Community law nor are they required to be fluent in French (the language of deliberation) or English (the second language in most Member States).

The omission of a requirement for proven knowledge of the legal order under which the appointed judges are going to serve is understandable in the 1950 s, but surely not acceptable now when a considerable body of legal principles and concepts have been developed by the court to underpin this novel legal order. Similarly, the

Articles
Making sure the child is heard I
$\begin{aligned} & \text { Re-defining charity for the } 21 \text { st century } \\ & \text { Society and Institute News }\end{aligned}$
Articles (cont'd)
Privacy and celebrity: an update
Liability of regulators for bank failures

requirement that a consensus judgment is reached at the end of deliberations that are secret and undertaken primarily in French (no interpreters are present), would suggest that linguistic skills, one of the most important tools in the art of persuasive argument, would be an essential qualification.

Of course such radical reform will require a "Convention" of expert judges, practitioners, academics and representatives of Governments to identify the problems that may arise and to ensure that appropriate solutions are found. It is absolutely fundamental that any reform should not jeopardise the general acceptance of the ECJ's rulings into the national legal order of the Member States. Such a Convention should at the very least propose a maximum number of judges, agree a list of conditions and minimum qualifications of eligibility for appointment, and devise an independent Appointments Commission to appoint the judges.

\section{Rosa Greaves}

Allen \& Overy Professor of European Law

Durham European Law Institute

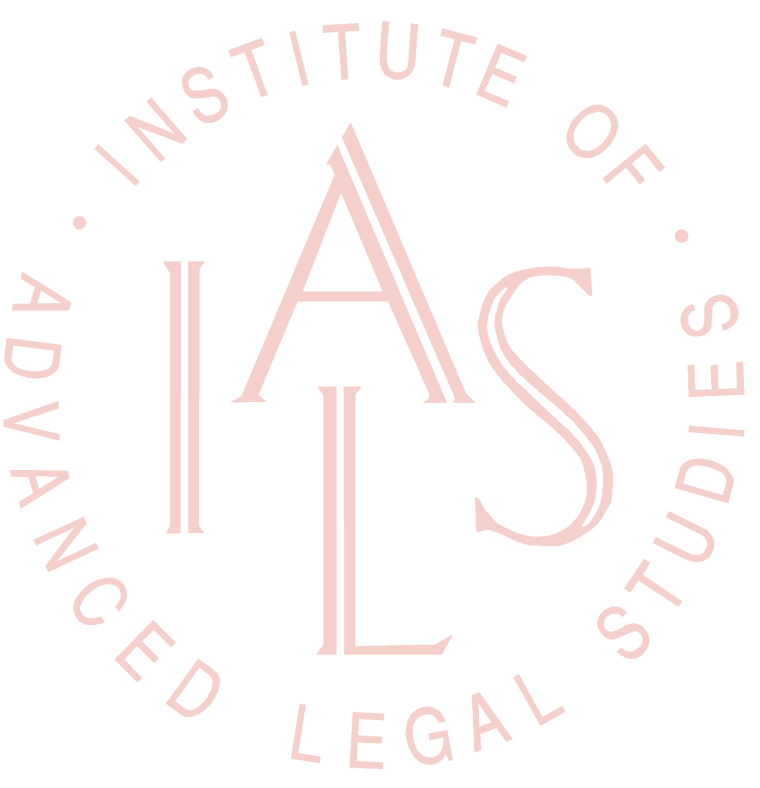

